\title{
COMMUNICATION BY TEXT IN THE PEDAGOGICAL INTERACTION FOR TEACHERS' PROFESSIONAL COMPETENCE
}

\author{
Desislava Siderova ${ }^{1}$
}

\begin{abstract}
In the present study, communication by texts is seen as a prerequisite for constructing textual competence through case studies in the university students' training. The thematic texts are oriented to nature-related concepts that create an integrative context of the learning (kindergarten children's poems in the pedagogical interaction are aimed at developing professional competence in future pre-school teachers). Nonparametric methods for nominal data are used (test of goodness of fit and test of independence). The predominant text-initiating technique (the descriptive one) in the case study predetermines the leading orientation of the students towards the knowledge about the natural world as part of the educational field "Environment" in the kindergarten (47.62\% of all the integration opportunities). The research shows that students in pedagogy find successful decisions on professional cases.
\end{abstract}

UDC Classification: 378, DOI: 10.12955/cbup.v7.1429

Keywords: nature, poem, concept, case study

\section{Introduction}

The change in the educational paradigm through the enhanced penetration of the competence approach in university didactics predetermines the discovery of specific educational priorities to be addressed in the context of the educational needs of the students themselves. The planning of text-centric training within the linguistic courses is considered to be promising in terms of increasing the quality of the educational service with the pedagogical students.

The purpose of the present study is to specify the educational priorities of the curriculum included in the preparation of linguodidactcs of the Bulgarian language in the area of textual competence as part of the professional competence of the pedagogical students who are preparing to be teachers of preschool children in the conditions of kindergarten.

Based on this study, criteria have been identified for the inclusion of literary texts in the pre-school educational process, by means of students acquiring the skills to take into consideration the age specifics of preschool children and the text characteristics of the speech product. Information about the various techniques of text creation is systemized, linked to the genres of productive and reproductive texts in pedagogical interaction with children in kindergarten.

\section{Theoretical framework}

In the framework of contextual learning, the parameters of textual competency of the future teachers of children are sought, which competence they will need for their successful realization in line with the European Qualifications Framework for Lifelong Learning (European Commission, 2009). It is in the realization of the transition from text centrism to anthropocentrism (educational content technological realization of the pedagogical interaction in the kindergarten) that the manifestations of the professional competency of the pre-school teacher are sought.

In the context of this study, we stick to the understanding of textual competence as a set of skills for building and adopting a linguistic text. It encompasses the rules that apply in a given language for constructing different types of constituents and applying the types of texturing mechanisms, as well as corresponding towards more specific competencies related to productive and/or only receptive handling of separate types of texts (Dobreva \& Savova, 2009, p. 237).

An important aspect for the study is the understanding in the spirit of constructivism of children's concepts as the child's "own understanding of the studied processes and phenomena" with "an individual, imaginary, open, integral and active character" (Petrova, 2005, p. 39). In the study, the concept of a natural object in the lyrical text is often of an anthropomorphic nature. In this case, the artistic text is considered to be a broader field in which the concept of the natural environment built up in childhood will be deployed, so far only at the pre-school age at a supportive level. Building the concept of a natural object by using the artistic text in pedagogical interaction is seen as the mastering of a cognitive development strategy that focuses on integrative knowledge. The merging of the literary image with the natural and scientific understanding of the natural objects is a stage characteristic of the

\footnotetext{
${ }^{1}$ Trakia University, Faculty of Education, Stara Zagora, Bulgaria, desiti@abv.bg
} 
child's knowledge, their differentiating being attached to the formation of concepts reinforced by the educational process in the school.

The research is also interested in creating texts as a result of communication with the original poetic text. The above-mentioned text creation can be seen as a "recomposing", understood as "a change in the content of the foreign text, without affecting the overall concept" (Tankova, 1998, p. 70). In this case, the child must preserve the source concentration for the natural object created by the author of the lyrical work, but build his or her own text from the communication with the primary one. It would be interesting to trace the extent to which the created source text in the process of pedagogical interaction follows the scientific ideas about the natural world or the ideas of the children brought about by literary communication.

\section{Diagnostic Procedure}

65 students in Pre-school and Primary School Pedagogy took part in the survey. They are trained at the Faculty of Education of Trakia University, Stara Zagora, Bulgaria.

65 different texts were used. Their authors are Bulgarian poets - classical and contemporary authors of literature for children. The main focus being directed at tracking the characteristic changes in the natural environment during different seasons with a special interest in living organisms in the given context. However, as far as works of literature on children are concerned, natural information is translated into artistic images of aesthetic value. This predetermines the use of the personification of natural objects and phenomena in a significant part of the texts. The direction of work on fictional texts with natural concepts is very suitable for the age of these children. This also predetermines the invariant situation of pedagogical interaction to which the student who is a future teacher of children has to find a methodical approach during the diagnostic procedure with the use of case studies as an instrument in the research (Figure 1).

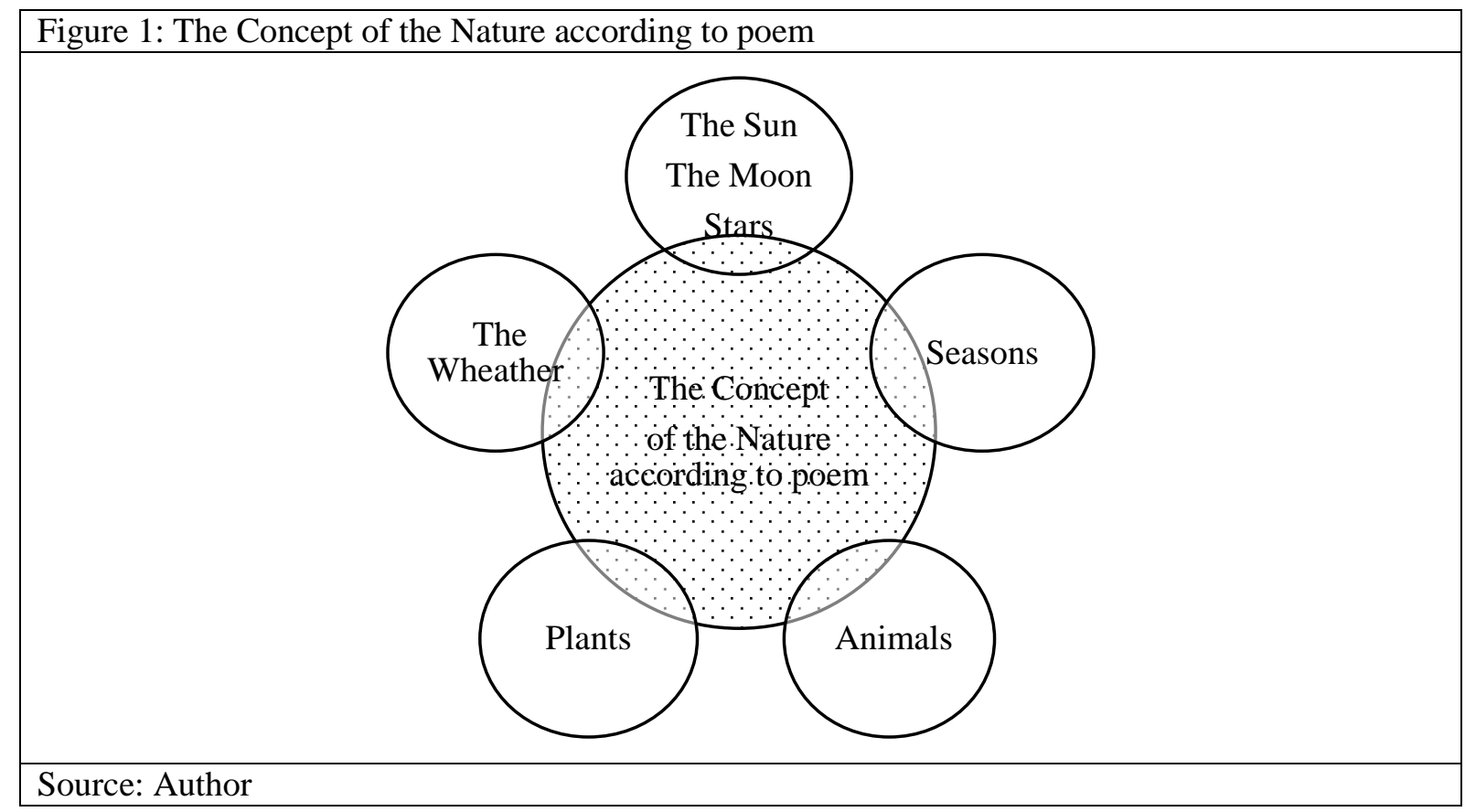

The study itself consisted of 2 strands which, on the one hand, track the students' theoretical knowledge of the text and, on the other - their ability to adapt them according to the age specifics of pre-school children and to transform them according to the specifics of the pedagogical interaction in kindergarten. For the application of the knowledge and skills in the implementation of contextual training within the framework of the university linguodidactics, an individual case study is submitted to the student on a paper carrier in the performed diagnostic procedure. This implies the application of a specific approach to the text predetermined by itself, but also by the peculiarities of its recipient the future kindergarten teacher - in their role as mediator in the triad of author - text - children. The communication with the text in the pedagogical interaction is seen as a prerequisite for constructing textual competence, which in turn is part of the professional competence of future teachers. In order to 
realize the aim of the research, the students perform a system of 10 tasks, united by the conceptual direction of the case study presented to the studied persons: to outline the leading parameters of the pedagogical interaction with the children in kindergarten based on the artistic text belonging to the poetic genre, taking into account its text specifics (Table 1).

\begin{tabular}{|l|l|}
\hline Table 1: Text-based tasks of the case study \\
\hline $\begin{array}{l}\text { Student determined } \\
\text { the text specificity of the case study }\end{array}$ & $\begin{array}{l}\text { Student determined } \\
\text { the pedagogical interaction } \\
\text { in the kindergarten }\end{array}$ \\
\hline $\begin{array}{l}\text { text as written text, artistic text, poem, predominant } \\
\text { text-inferring technique }\end{array}$ & core of the state educational standard \\
\hline link between the topic and the title of the text & $\begin{array}{l}\text { age group in the kindergarten the text may be } \\
\text { included }\end{array}$ \\
\hline $\begin{array}{l}\text { idea of the text (understanding of the author's } \\
\text { intention) }\end{array}$ & $\begin{array}{l}\text { targeting aimed at mastering competencies by pre- } \\
\text { school children }\end{array}$ \\
\hline $\begin{array}{l}\text { Keywords leading to the leading lexico-thematic } \\
\text { fields }\end{array}$ & $\begin{array}{l}\text { texts that children can create as a result of the } \\
\text { literary communication }\end{array}$ \\
\hline & questions on the content of the text of the case study \\
\cline { 2 - 2 } & $\begin{array}{l}\text { educational field should be implemented in the } \\
\text { integration }\end{array}$ \\
\hline Source: Author &
\end{tabular}

\section{Results and Discussion}

The results of the diagnostic procedure that can be inferred with regard to the knowledge of the text specifics and the planning of pedagogical interaction will be presented below consistently, although the activities for their mastering take place synchronously.

Results regarding the described text specificity

The majority of students correctly define the text as written -49 students, representing $75.38 \%$ of the total sample; artistic - 63 (96.92\%); the genre is identified as a poem by 64 of the surveyed persons (98.46\%). Regarding the predominant text-inferring technique, 37 students $(56.92 \%)$ are directed to the descriptive one. Concerning the link between the topic and the title of the text, the data show inaccuracies in understanding. The largest number of students consider that the title of the work is related both to the function and to the theme of the text -27 students $(41.53 \%), 18$ - only with the topic (a relative share of 27.69\%) and $11(16.92 \%)$ - only with the function of the text. Most of the texts do not contain in the title a signal for their functional orientation.

Drawing the idea leads to an understanding of the author's intention when creating the text, and this should evolve into adequate targeting aimed at mastering competencies by pre-school children. Expectations in this direction are not sufficiently justified. Students formulate keywords leading to the leading lexico-thematic fields, as well as the idea of the text, but find it difficult to point out the competencies around which the pedagogical interaction with the children in the kindergarten is centered. For example, about $1 / 5$ of all people surveyed -14 students $(21.54 \%)$ - demonstrate a refusal to indicate competencies, as the reason can be found in the "openness" of the task - it requires reading comprehension of the source text.

Results concerning the pedagogical interaction

Initially, the students had to identify the core of the state standard on pre-school education (Ministry of Education and Science, 2016, pp 94-97) in the educational field "Bulgarian Language and Literature", which is most closely related to the text of the case. That is "Perception of a literary work" which was truly identified by 46 of the surveyed students (70.77\%).

The students also determined in which age group in the kindergarten the text of the submitted case may be included in the educational process. These were prioritized in the following age groups: 28 students of all people surveyed $(43.08 \%)$ to the second age group (4-5 year-old children) and 21 (32.31\%) to the third preparatory school age group (5-6 years-old children). Only 4 students $(6.15 \%)$ chose the beginning of pre-school education, and 6 (9.23\%) - the "exit" of that educational stage. Here, along with the specificity of the artistic construction itself, the text volume can be taken into account as an average number of words, an average number of sentences and an average number of 
words per sentence. The average number of words used in the study is 62 and the average number of sentences is 6 . For the last variable, an average number of sentence words, the most common value in the distribution is 9 and it is 9 times available in the sample (the mode of the sample is $\mathbf{M}_{0}=9$ and the median is $M_{d n}=13$ ). This data outlines the preference of the students to the intermediate educational levels in the kindergarten as regards the inclusion of the poetic texts provided in the case study.

The table below presents the children's texts that they can create as a result of the literary communication. They are ranged according to their correspondence with the text.

An analysis of one variable is carried out, namely, finding out whether university students prefer a particular type of text that children can create as a result of literary communication. A Chi-Square $\left(\chi^{2}\right)$ test of goodness of fit is applied. Under the null hypothesis $\left(\mathrm{H}_{0}\right)$, students will not prefer a particular type of text that children can create as a result of literary communication. The critical value for $\chi^{2}$ at the 0.05 level with the number of degrees of freedom equal to 4 is 9.49 . The null hypothesis $\left(\mathrm{H}_{0}\right)$ is rejected, the calculated value of $\chi^{2}$ is greater than the critical value $(11.28>9.49)$. Students ranking the first-line mostly the descriptive texts $(35,85 \%)$, demonstrating preference for them as secondary ones, resulting from the communication of children with the original text with the concept of nature. The students' preference is outlined in the creation of a textual description correlating with the derived predominant text-inferring technique of the source text (the descriptive one). This in turn is predetermined by the leading concept in the texts included in the case study, namely the seasonal changes in nature (Table 2).

\begin{tabular}{|l|c|c|c|c|c|c|}
\hline Table 2: Creating texts as a result of communication with the source text \\
\hline \multirow{2}{*}{$\begin{array}{l}\text { Specified secondary } \\
\text { texts }\end{array}$} & $\begin{array}{c}\text { Ranged according to the correspondence with the text } \\
\text { range }\end{array}$ & $\begin{array}{c}\text { Second } \\
\text { range }\end{array}$ & $\begin{array}{c}\text { Third } \\
\text { range }\end{array}$ & $\begin{array}{c}\text { Fourth } \\
\text { range }\end{array}$ & $\begin{array}{c}\text { Fifth } \\
\text { range }\end{array}$ & Total \\
\hline Text description & 19 & 15 & 8 & 5 & 3 & $\mathbf{5 0}$ \\
\hline Text about experience & 5 & 10 & 10 & 12 & 11 & $\mathbf{4 8}$ \\
\hline $\begin{array}{l}\text { Text based on } \\
\text { imagination }\end{array}$ & 13 & 10 & 9 & 5 & 10 & $\mathbf{4 7}$ \\
\hline $\begin{array}{l}\text { Text on some word } \\
\text { basis }\end{array}$ & 9 & 8 & 11 & 12 & 13 & $\mathbf{5 3}$ \\
\hline Text based on images & 7 & 7 & 7 & 10 & 6 & $\mathbf{3 7}$ \\
\hline
\end{tabular}

Source: Author

Interesting is the data regarding which educational field should be implemented in integration within the pedagogical situation in the field "Bulgarian language and literature" in kindergarten, which is related to the text of the case study (Figure 2).

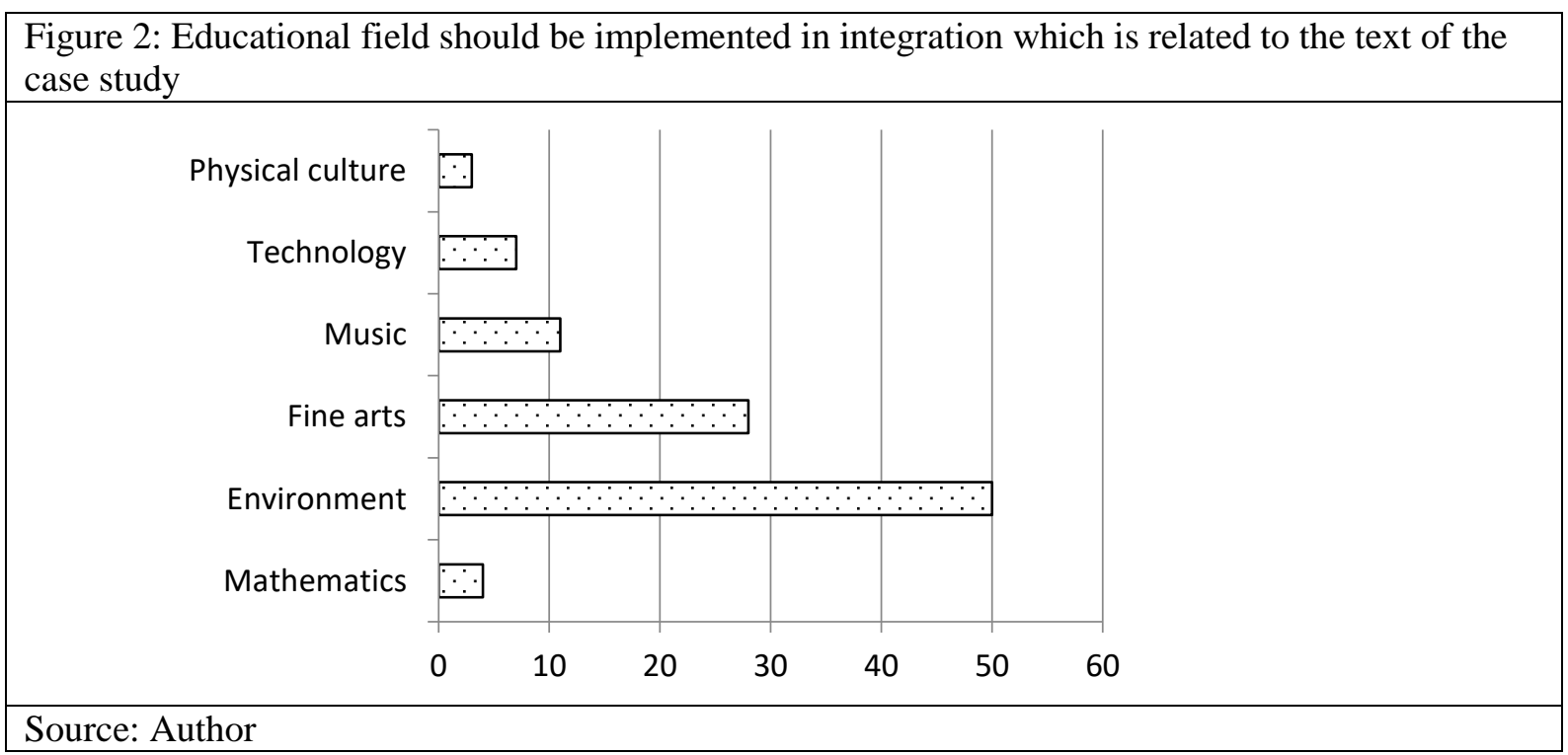

The state standard on pre-school education, which logically follows from the leading concept in the texts, namely the pre-school field "Environment" (Ministry of Education and Science, 2016, pp 99- 
102), has been marked by 50 students, representing $47.62 \%$ of all the mentioned integration opportunities (105). It is followed by "Fine Arts", which is mentioned by 28 of the students (with a relative share of 26.67\%) and in the educational area "Music" with $12.38 \%$ - 13 students. The second and third place of the arts-related directions is connected to the syncretism in the aesthetic sphere. The original text is a work of art literature and is organically integrated with them. We have already noted that students demonstrate a preference for descriptive texts. It is interesting to see whether the students who have designated the descriptive texts in the first place as the most appropriate in the creation of secondary texts have also indicated the educational field "Environment" for an integrative context in the pedagogical interaction. An Independence Test (Chi-Square $\chi^{2}$ test of independence) is used. It is assumed that students who have indicated the descriptive texts as secondary with first grade will in most cases mark the educational field "Environment" as an integrative context for the pedagogical situation in kindergarten compared to the students who did not specify the descriptive texts with the first ranking. The null hypothesis $\left(\mathrm{H}_{0}\right)$ states that the two values are independent. Students who pointed out the descriptive tests, as well as those who did not specify them, will have the same share in marking the education field "Environment" as an integrative context. A cross-table of the survey participants is used. The critical value at level 0.05 and at 1 degree of freedom is 3.84. The calculated value of $\chi^{2}$ is less than the critical value $(0.2<3.84)$, and in this case the null hypothesis $\left(\mathrm{H}_{0}\right)$ cannot be rejected. It has been established that there is no connection between the rankings of the descriptive tests as first and the designation by the students of educational field "Environment".

The students were also asked to formulate questions on the content of the text of the case study in the framework of the discussion, taking into account the age specificities and the specifics of pedagogical interaction in the educational field "Bulgarian Language and Literature" in kindergarten (Table 3).

\begin{tabular}{|c|c|}
\hline The concept of "nature" in the poetical text & Questions to the literary text \\
\hline $\begin{array}{l}\text { The Sun } \\
\text { The Moon } \\
\text { Stars }\end{array}$ & $\begin{array}{l}\text { Who rises in the sky? } \\
\text { Who does the sun shake hands with in the morning? } \\
\text { What does the sun do with the snow? } \\
\text { What do the stars do? } \\
\text { What are the rays of the sun in the evening? } \\
\text { How do the mountain and the sun part in the evening? }\end{array}$ \\
\hline The weather & $\begin{array}{l}\text { Where is the little cloud going? Where is it flying to? } \\
\text { What will shine when the rain stops? } \\
\text { What happens with the forest when it rains? } \\
\text { What did the wind do during in the night? } \\
\text { What can you see above the earth in summer when it is } \\
\text { very hot? } \\
\text { How does the snow fall? }\end{array}$ \\
\hline Seasons & $\begin{array}{l}\text { Why do leaves fall? } \\
\text { What happens to the trees in spring? } \\
\text { What do birds do in spring? }\end{array}$ \\
\hline Plants & $\begin{array}{l}\text { Why has the pine tree frozen? Why can't it fly as the } \\
\text { birds? And where do they fly to? } \\
\text { Where has the lilac blossomed? } \\
\text { What do the thick weeping willows do? } \\
\text { What can we pick in the forest? } \\
\text { What are the flowers that have blossomed? Describe the } \\
\text { flowers. }\end{array}$ \\
\hline Animals & $\begin{array}{l}\text { Why do birds fly south? } \\
\text { Who is awakening from hibernation? } \\
\text { Which animals hide under the mushroom? } \\
\text { Where did the ant stop? } \\
\text { When do the crickets fall silent? } \\
\text { What did the little rabbit do when he saw the snow? } \\
\text { What are the songs of the nightingale? } \\
\text { By what traces do we recognize the squirrel? }\end{array}$ \\
\hline
\end{tabular}

Source: Author 
The most common value in the distribution are 6 questions: it occurs 8 times in the sample, so consequently the mode is $\mathrm{M}_{0}=6$. The mean value $(\mathrm{M}=6.91)$ and the median $\left(\mathrm{M}_{\mathrm{dn}}=6.5\right)$ are close which indicates that the variable "questions asked to the text" by students who are future educators is approximately normal. With 15 students $(23.08 \%)$ there is a refusal to formulate questions, and that skill is considered by linguodidactics as important because it builds the skeleton of the heuristic talk within the pedagogical interaction.

The structure of the questions asked from a formal-semantic point of view is also interesting. The small relative share of the lines-incentives (11.41\%), which are complex sentences, is explained by the age specifics regarding the use of clear and specific formulations in the presentation of stimuli. Dominant are sentences with full question words, such as Who? Where? When? What? How?, with only $1.68 \%$ of the relative share of questions in the composition of which the Why? word present, seeking communicative intent. A positive impression is given by the fact that the students avoid questions with question marks that require a yes or no answer - in this case study only of $2.68 \%$ relative share (Table 3 ).

\section{Conclusion}

The study shows that pedagogy students find successful decisions on professional cases. They help to adequately diagnose the level of textual competence. This is seen as part of the professional competence of future pedagogues. Thanks to the acquired competencies at the university, future teachers can successfully perform pedagogical interaction in kindergarten under changing conditions and an integrative context. This is the case with communication with texts in children from different age groups. However, greater attention is needed towards the mastery of skills for adequate targeting in pedagogical interaction. This also guarantees an adequate technological build-up of the pedagogical situation in its planning and realization in a real pedagogical environment.

\section{References}

Dobreva, E., \& Savova, I. (2009). Tekst \& diskurs [Text \& Discourse]. Veliko Turnovo: Faber. ISBN 978-954-400-107-0. European Commission (2009). European Qualifications Framework for Lifelong Learning (EQF). Retrieved March, 10, 2019, from https://ec.europa.eu/ploteus/sites/eac-eqf/files/broch_bg.pdf.

Ministry of Education and Science (2016, June 17). Naredba No. 5 ot 03.06.2016 g. za preduchilishtnoto obrazovanie. Darzhaven Vestnik, 46, 88-111 [Ordinance No 5 of June, 03, 2016 on Pre-school Education]. ISSN 0205-0900.

Petrova, V. (2005). Detskite kontsepti za prirodata [Children's Concept of the Nature]. Stara Zagora: Kota. ISBN 954-314024-3.

Tankova, R. (1998). Modelirane na tekst [Text Modeling]. Plovdiv: Sema 2001. ISBN 954-8833-04-2. 